\title{
Gallbladder Cancer Pathologic Regional Lymph Nodes TNM Finding v8
}

National Cancer Institute

\section{Source}

National Cancer Institute. Gallbladder Cancer Pathologic Regional Lymph Nodes TNM

Finding v8. NCI Thesaurus. Code C134655.

A pathologic finding about one or more characteristics of gallbladder cancer, following the rules of the TNM AJCC V8 classification system as they pertain to stag ing of regional lymph nodes. 